\title{
Het kabinetsvoorstel tot verruiming van de Embryowet: een halve stap vooruit
}

Citation for published version (APA):

Dondorp, W., Ploem, M. C., \& de Wert, G. (2016). Het kabinetsvoorstel tot verruiming van de Embryowet: een halve stap vooruit. Tijdschrift voor Gezondheidsrecht, 40(8), 536-544.

https://doi.org/10.5553/TvGR/016508742016040008005

Document status and date:

Published: 01/01/2016

DOI:

10.5553/TvGR/016508742016040008005

Document Version:

Publisher's PDF, also known as Version of record

Document license:

Taverne

Please check the document version of this publication:

- A submitted manuscript is the version of the article upon submission and before peer-review. There can be important differences between the submitted version and the official published version of record.

People interested in the research are advised to contact the author for the final version of the publication, or visit the DOI to the publisher's website.

- The final author version and the galley proof are versions of the publication after peer review.

- The final published version features the final layout of the paper including the volume, issue and page numbers.

Link to publication

\footnotetext{
General rights rights.

- You may freely distribute the URL identifying the publication in the public portal. please follow below link for the End User Agreement:

www.umlib.nl/taverne-license

Take down policy

If you believe that this document breaches copyright please contact us at:

repository@maastrichtuniversity.nl

providing details and we will investigate your claim.
}

Copyright and moral rights for the publications made accessible in the public portal are retained by the authors and/or other copyright owners and it is a condition of accessing publications that users recognise and abide by the legal requirements associated with these

- Users may download and print one copy of any publication from the public portal for the purpose of private study or research.

- You may not further distribute the material or use it for any profit-making activity or commercial gain

If the publication is distributed under the terms of Article $25 \mathrm{fa}$ of the Dutch Copyright Act, indicated by the "Taverne" license above, 


\title{
Het kabinetsvoorstel tot verruiming van de Embryowet: een halve stap vooruit
}

\author{
Dr. W.J. Dondorp, Mr. dr. M.C. Ploem \& Prof. dr. G.M.W.R. de Wert ${ }^{*}$
}

\section{Inleiding}

In het dossier 'het speciaal tot stand brengen van embryo's voor wetenschappelijk onderzoek' kwam onlangs, na een lange radiostilte, beweging. In de twee evaluaties van de Embryowet (EW) in $2005^{1}$ en $2012^{2}$ is bepleit het verbod op het doen ontstaan van embryo's voor andere doeleinden dan zwangerschap (artikel 24a EW) op te heffen, maar het kabinetsstandpunt ${ }^{3}$ dat op de tweede evaluatie volgde, was afwijzend. De minister van VWS maakte daarin duidelijk het verbod niet te zullen opheffen, maar liet wel weten de deur niet helemaal op slot te willen houden:

‘...) Wanneer het onontkoombaar is dat voor de klinische toepassing [van veelbelovend wetenschappelijk onderzoek] embryo's tot stand moeten worden gebracht, (...) is dit een goede reden om eerder gemaakte afwegingen opnieuw te bezien. Op dit moment is het voor mij niet duidelijk of er al sprake is van zulke (...) ontwikkelingen. (...) Daarom zal ik laten onderzoeken of er veelbelovende medische ontwikkelingen zijn waarvan het vrij aannemelijk is dat deze op het punt staan om in de kliniek te worden geïntroduceerd wanneer het verbod op het tot stand brengen van embryo's voor onderzoek wordt opgeheven.'

Het bedoelde onderzoek is intussen uitgevoerd en de resultaten hiervan werden op 6 mei 2015 aan de Tweede Kamer aangeboden. ${ }^{5}$ In het onderzoeksrapport ${ }^{6}$ wordt (net als in de beide evaluatierapporten) geconcludeerd dat fundamenteel onderzoek naar de vroege embryonale ontwikkeling alsmede preklinisch onderzoek naar de veiligheid van nieuwe voortplantingstechnieken door het verbod belemmerd worden. Blijkens de op 2 juni

* Wybo Dondorp is UHD biomedische ethiek bij de Universiteit Maastricht, Afd. Metamedica en onderzoeksscholen CAPHRI en GROW. Corrette Ploem is UD gezondheidsrecht bij het AMC, Afd. Sociale Geneeskunde en lid van de redactie van dit tijdschrift. Guido de Wert is hoogleraar biomedische ethiek bij de Universiteit Maastricht, Afd. Metamedica en onderzoeksscholen CAPHRI en GROW.

1 E.T.M. Olsthoorn-Heim, G.M.W.R. de Wert, H.B. Winter, T.A.M. te Braake, M.J. Heineman, A. Middelkamp, C.J. Nierse, Evaluatie Embryowet, Den Haag: ZonMw 2006.

2 H.B. Winter, W.J. Dondorp, M.C. Ploem, N.O.M. Woestenburg, C.P.M. Akerboom, J. Legemaate, G.M.W.R. de Wert, Evaluatie Embryowet en Wet donorgegevens kunstmatige bevruchting, Den Haag: ZonMw 2012.

3 Kamerstukken II 2012/13, 30486, 5.

4 Ibid, p. 11.

$5 \quad$ Kamerstukken II 2014/15, $29323,94$.

6 J. Eeuwijk e.a., Onderzoek naar speciaal kweken. Een onderzoek in opdracht van het ministerie van Volksgezondheid, Welzijn en Sport, Rotterdam: Pallas 2015. 
jongstleden aan de Tweede Kamer gestuurde brief $^{7}$ heeft de regering op de valreep ingezien dat het nu echt dringend geboden is de koers te verleggen. Het voornemen is artikel 24a dusdanig te verruimen dat het onder voorwaarden wordt toegestaan menselijke embryo's te creëren voor wetenschappelijk onderzoek op drie nader omschreven gebieden. In deze bijdrage schetsen we eerst de achtergrond van het regeringsvoorstel (paragraaf 2). Daarna zetten we uiteen waar de aangekondigde verruiming van de Embryowet nu precies op neerkomt (paragraaf 3). Vervolgens zullen we aangeven hoe we tegen de wetsverruiming aankijken, waarbij we tevens aandacht zullen schenken aan wat daarover door anderen is gezegd (paragraaf 4). We ronden af met enkele concluderende opmerkingen (paragraaf 5).

\section{Achtergrond en aanleiding van het regeringsvoorstel}

De tijdelijkheid van het verbod in artikel 24a EW is in de constructie van de Embryowet nadrukkelijk ingebouwd. In artikel 33 lid 2 EW werd bepaald dat dit onderdeel 'vervalt op een bij koninklijk besluit te bepalen tijdstip' en dat 'de voordracht voor dat besluit wordt gedaan na verloop van ten hoogste vijf jaren na het tijdstip van het in werking treden van dat artikelonderdeel'. Verder bevat de wet bepalingen (artikel 9, artikel 11 en artikel 24 sub b) die in werking zullen treden nadat het verbod is opgeheven. Daarin worden de voorwaarden uitgewerkt waaronder embryo's alsdan tot stand gebracht mogen worden voor wetenschappelijk onderzoek en therapeutische toepassingen. De reden voor deze bijzondere constructie hing samen met de toen nog nagestreefde ratificatie van het Verdrag inzake de rechten van de mens en de biogeneeskunde (VRMB) van de Raad van Europa. ${ }^{8}$ De wetgever wilde voorkomen dat ons land geen ruimte zou hebben om een voorbehoud te maken bij de overeenkomstige verbodsbepaling in dat verdrag, ${ }^{9}$ en dan voor lange tijd aan dat verbod zou vastzitten. ${ }^{10}$ Blijkens de memorie van toelichting zag de wetgever geen principiële ethische of juridische redenen voor een verbod, maar besloot hij tot een tijdelijke pas op de plaats omdat het maatschappelijke draagvlak voor het toestaan van het creeren van embryo's voor onderzoek als 'nog te smal' beoordeeld werd, terwijl van een daadwerkelijke belemmering van belangrijk wetenschappelijk onderzoek door een moratorium op dat moment nog geen sprake zou zijn (hetgeen toen overigens al door o.a. de Gezondheidsraad werd tegengesproken ${ }^{11}$ ) en omdat de vrees bestond internationaal te veel uit de pas te lopen. Wel vond de wetgever dat te zijner tijd voor onderzoek met speciaal tot stand te brengen embryo's strengere voorwaarden zouden moeten gelden dan voor onderzoek met na IVF overgebleven 'restembryo's'. Terwijl in artikel $10 \mathrm{EW}$ is bepaald dat onderzoek met restembryo's (onder nadere voorwaarden van vrijwillige en geïnformeerde terbeschikkingstelling, subsidiariteit en kwaliteit) is toegestaan als het 'redelijkerwijs aan-

$7 \quad$ Kamerstukken II 2015/16, 29323, 101.

8 Het kabinet heeft bij brief van 20 maart 2015 laten weten dat het zal afzien van ratificatie van het VRMB en zijn additionele protocollen. Kamerstukken I 2014/15, 34000 XVI, E.

9 Art. 18 sub 2 Biogeneeskunde-verdrag: 'The creation of human embryos for research purposes is prohibited.' Het maken van een voorbehoud bij het verdrag is slechts mogelijk voor landen waarvan de op het tijdstip van ratificatie bestaande wetgeving afwijkt van de bepalingen van het verdrag (art. 36 sub 1).

10 Zie MvT Embryowet, Kamerstukken II 2000/01, 27423, 3, p. 28-29 en p. 59; W. Dondorp, 'De toekomstbestendigheid van de Embryowet', TvGR 2007, p. 72-75.

11 Gezondheidsraad, IVF: afrondende advisering, Den Haag: Gezondheidsraad 1998. 
nemelijk is dat het onderzoek zal leiden tot de vaststelling van nieuwe inzichten op het terrein van de geneeskunde', zou op grond van artikel $11 \mathrm{EW}$ onderzoek met speciaal tot stand te brengen embryo's slechts toelaatbaar zijn onder de verdere beperking dat het daarbij zou moeten gaan om nieuwe inzichten 'op het terrein van onvruchtbaarheid, (...) kunstmatige voortplantingstechnieken, (...) erfelijke of aangeboren aandoeningen, of (...) de transplantatiegeneeskunde', mits het onderzoek niet ook met restembryo's zou kunnen worden gedaan. Dat dat laatste niet altijd mogelijk is, hangt samen met het feit dat voor sommige onderzoeksdoelen restembryo's geen geschikt materiaal vormen. Dat geldt voor het meeste onderzoek naar de effectiviteit en veiligheid van nieuwe voortplantingstechnieken. Restembryo's zijn immers ontstaan uit voortplantingsmateriaal dat niet is blootgesteld aan de te onderzoeken interventies. In alle gevallen is het aan de Centrale Commissie Mensgebonden Onderzoek (CCMO) om te beoordelen of onderzoeksprotocollen aan de wettelijke voorwaarden voldoen.

In 2007 werd de tweede hierboven geciteerde volzin van het tweede lid van artikel $33 \mathrm{EW}$ geschrapt, waardoor de aankondigde opheffing niet langer aan een specifiek tijdpad gebonden was en de facto op de lange baan kon worden geschoven. Dit weerspiegelde de na de totstandkoming van de Embryowet veranderde samenstelling van de regeringscoalitie.

\section{Inhoud van en kanttekeningen bij het verruimingsvoorstel}

Maar nu, zo valt uit de brief van de minister van VWS op te maken, zal het verbod om embryo's speciaal voor onderzoek tot stand te brengen (hieronder verder: 'het verbod') alsnog worden opgeheven. Opmerkelijk genoeg verwijst de regering in haar brief met geen woord naar wat met het oog op die voorziene opheffing reeds in de Embryowet geregeld is. De stelling in de brief dat 'het volledig loslaten van het verbod nog niet aan de orde is', suggereert ten onrechte dat dat aanvankelijk wel de bedoeling van de wetgever was. Zoals hierboven is uitgelegd zijn in de Embryowet duidelijke voorwaarden opgenomen die na opheffing van het verbod grenzen moeten stellen aan het doen ontstaan van embryo's voor andere doelen dan zwangerschap, in het bijzonder de beperking van toegelaten onderzoeksterreinen. Uit de brief moet worden opgemaakt dat de regering de formulering daarvan in artikel $11 \mathrm{EW}$ kennelijk te ruim vindt, want zij komt met een verdere beperking op dit punt. Terwijl artikel $11 \mathrm{EW}$ ruimte laat voor allerlei vormen van fundamenteel ontwikkelingsbiologisch onderzoek (naar bevruchting, vroege embryonale ontwikkeling et cetera) indien 'redelijkerwijs aannemelijk is dat het zal leiden tot nieuwe inzichten' op de in dat artikel genoemde terreinen, wil de regering het verbod uitsluitend opheffen voor onderzoek dat 'direct relevant (is) voor de klinische toepassing'. Onderzoek waarvoor dat niet geldt (de brief noemt transplantatiegeneeskunde en fundamenteel onderzoek) wordt nadrukkelijk uitgesloten. Hierbij zijn kanttekeningen te plaatsen.

In de eerste plaats: de nadrukkelijke uitsluiting van transplantatiegeneeskunde uit het lijstje van aanvaardbare terreinen van onderzoek waarvoor na opheffing van het verbod embryo's tot stand mogen worden gebracht, wordt niet onderbouwd. De suggestie dat met onderzoek op dat terrein geen actuele klinische toepassing wordt gediend is wellicht ingegeven door de gedachte dat sinds de ontdekking van 'induced pluripotent stem cells' (iPScellen) voor de ontwikkeling van celtransplantietherapieën geen onderzoek met humane 
embryonale stamcellen (hES-cellen) meer nodig is. Of dat klopt, is nog maar de vraag. Zoals opgemerkt in het rapport van de laatste wetsevaluatie, zijn onderzoekers het er over eens dat beter begrip van de biologie van de celprogrammering een voorwaarde is voor de ontwikkeling van bruikbare en veilige celtherapieprotocollen, en dat zulk onderzoek niet mogelijk is zonder daarin beide celtypen (niet alleen iPS-cellen, maar ook hES-cellen) te betrekken'. ${ }^{12}$ Volgens het rapport blijft ook 'somatic cell nuclear transfer' (SCNT), ondanks de technische en praktische problemen rond die techniek, belangrijk voor het onderzoek naar de reprogrammering van somatische cellen en dus voor de ontwikkeling van de beoogde therapieën. Bij SCNT worden onvermijdelijk embryo's tot stand gebracht.

Dit rakt meteen aan een tweede punt: het onderscheid tussen fundamenteel en klinisch relevant onderzoek is in de praktijk minder scherp dan in de brief wordt gesuggereerd. Het een gaat op enig moment over in het ander, maar waar ligt de grens? De regering lijkt een ruime uitleg van 'directe relevantie voor klinische toepassing' voor te staan. Althans, dat zou men kunnen afleiden uit de voorbeelden die in de brief worden genoemd van onderzoek met speciaal tot stand te brengen embryo's dat in beginsel kan worden toegestaan. Een van die voorbeelden is 'behandeling van onvruchtbaarheid met uit stamcellen verkregen geslachtscellen'. Klinische toepassing daarvan (voortplanting met 'kunstmatige geslachtscellen') is nog ver weg, de brief spreekt van ten minste tien tot twintig jaar. Maar ook als het klopt dat de regering een ruime opvatting van directe klinische relevantie wil hanteren, dat wil nog niet zeggen dat de CCMO, de instantie die embryo-onderzoek moet beoordelen en goedkeuren, daar straks net zo over denkt.

Bij een strikte interpretatie geldt dat voor onderzoek met speciaal tot stand gebrachte embryo's gericht op een beter begrip van bevruchting en embryonale ontwikkeling in Nederland voorlopig geen ruimte komt, ook als het naar verwachting kan bijdragen aan belangrijke medische kennis en de ontwikkeling van toekomstige therapieën. Maar als alleen onderzoek naar toepassingen die al op de drempel van de kliniek staan wordt toegelaten, gaat men er kennelijk van uit dat het daaraan voorafgaande (ook fundamentele) onderzoek wel in het buitenland zal plaatsvinden. Zoals o.a. de Gezondheidsraad heeft opgemerkt, is dat moreel dubieus: 'Wie zou willen mikken op in het buitenland te verkrijgen resultaten van in ons land verboden onderzoek, neemt zichzelf de argumenten voor een geloofwaardige onderbouwing van dat verbod uit handen. ${ }^{\text {,13 }}$

Een derde kanttekening betreft de vraag of het gedetailleerd willen afbakenen van toegelaten onderzoeksterreinen wel verstandig is, omdat de stand van de wetenschap voortdurend verandert. Zo werd in de eerste schets voor de huidige Embryowet in een brief aan de Tweede Kamer (maart 1995) nog niet over transplantatiegeneeskunde als mogelijk toepassingsgebied van embryo-onderzoek gesproken. ${ }^{14}$ Op grond van een advies van de Gezondheidsraad ${ }^{15}$ over onderzoek met embryonale stamcellen, iets wat zich toen als een revolutionaire nieuwe wetenschappelijke ontwikkeling aankondigde, is zij bij de uiteindelijke redactie van artikel $11 \mathrm{EW}$ toegevoegd aan de drieslag 'onvruchtbaarheid, kunstmatige voortplantingstechnieken, erfelijke of aangeboren aandoeningen', om nu dus weer uit dat

12 Winter e.a. 2012, a.w., p. 190-191.

13 Gezondheidsraad 1998, a.w..

14 Kamerstukken II 1994/95, 23016, 7. p. 16-17.

15 Gezondheidsraad, Onderzoek met embryonale stamcellen. Signalement ten behoeve van aangekondigde wetgeving, Den Haag: Gezondheidsraad 1997. 
rijtje te verdwijnen. Het jojo-effect dat hier zichtbaar wordt, staat haaks op het algemene streven naar een consistent wetgevingsbeleid. Om te voorkomen dat wetgeving te zeer afhankelijk wordt van de toevallige stand van de wetenschap en debatten over de interpretatie daarvan, heeft de Gezondheidsraad in zijn toenmalige advies uit 1997 al bepleit om de beoogde limitatieve opsomming van toegelaten onderzoeksterreinen te vervangen door een meer algemene en open formulering die onderstreept dat menselijke embryo's alleen mogen worden gebruikt voor onderzoek waarvan het belang voor de volksgezondheid evident is. Uiteindelijk is die benadering wel gevolgd bij de redactie van artikel $10 \mathrm{EW}$ (onderzoek met restembryo's moet naar verwachting kunnen bijdragen aan nieuwe inzichten op het terrein van de geneeskunde), terwijl in artikel 11 (onderzoek met speciaal te kweken embryo's) het limitatieve rijtje van onderzoeksterreinen is blijven staan, dat met het huidige regeringsvoornemen dus opnieuw zou worden ingeperkt. Overigens zij hier nog opgemerkt dat 'mitochondriale donatie', in de brief genoemd als voorbeeld van een klinisch relevante toepassing waarvoor opheffing van het verbod gewenst zou zijn, strikt genomen een vorm van transplantatiegeneeskunde is. Bij de verschillende varianten van deze techniek wordt beoogd vrouwen met afwijkingen in het mitochondriale DNA in staat te stellen zich voort te planten zonder die afwijkingen en daardoor veroorzaakte ziekte aan het nageslacht door te geven. Om dat te bereiken wordt het deel van de eicel van de wensmoeder waarin zich de zieke mitochondriën bevinden (organellen die zorgen voor de energiehuishouding van de cel) vervangen door een gezond overeenkomstig deel van een donoreicel. ${ }^{16}$ Dat dit straks wel zou zijn toegestaan, terwijl 'transplantatiegeneeskunde' blijft uitgesloten, laat zien dat het precies afbakenen van onderzoeksterreinen en toepassingen waarvoor het verbod al wel of voorlopig nog niet zou mogen worden opgeheven minder eenvoudig is dan kennelijk gedacht en in de praktijk een van de belangrijkste doelen van wetgeving: het stellen van heldere normen, kan ondergraven.

\section{Reacties en nadere beschouwing}

In de reacties van de Tweede Kamerfracties op het verruimingsvoorstel van de regering, zoals naar voren gebracht tijdens het schriftelijke overleg hierover, kunnen drie visies worden onderscheiden. ${ }^{17}$ Ten eerste: degenen die menselijke embryo's beschouwen als volledig beschermwaardige leden van de mensengemeenschap, vinden dat iedere vorm van 'instrumentaliserend' embryo-onderzoek verboden moet zijn, ${ }^{18}$ dus ook het in de huidige Embryowet onder voorwaarden toegestane onderzoek met restembryo's. Ten tweede: degenen die onderzoek met restembryo's (onder voorwaarden) wel aanvaardbaar vinden, maar principiële bezwaren hebben tegen het creëren van embryo's voor onderzoek, kun-

16 J. Richardson,L. Irving, L.A. Hyslop, M. Choudhary, A. Murdoch, D.M. Turnbull, M. Herbert, 'Concise reviews: Assisted reproductive technologies to prevent transmission of mitochondrial DNA disease', Stem Cells (33) 2015 33, p. 639-645.

17 Kamerstukken II 2016/17, 29323, 105.

18 'Instrumentaliserend' wil zeggen dat het embryo louter als middel wordt gebruikt voor een buiten zichzelf en zijn mogelijke verdere ontwikkeling gelegen doel. Het eerste wetsvoorstel Embryowet uit 1992 stond alleen niet-instrumentaliserend onderzoek met menselijke embryo's toe (observationeel onderzoek zonder risico's voor het embryo of onderzoek dat de ontwikkeling van het embryo in kwestie ten goede zou kunnen komen). 
nen zich om die reden niet vinden in het voornemen de Embryowet op dit punt aan te passen. Ten derde: degenen die in normatief opzicht geen wezenlijk verschil zien tussen onderzoek met restembryo's en - als restembryo's niet bruikbaar of beschikbaar zijn - met speciaal tot stand te brengen embryo's, vragen zich af waarom na opheffing van het verbod in artikel 24a EW de deur maar op zo'n heel klein kiertje wordt gezet.

De eerstgenoemde visie (zie de vragen van ChristenUnie en SGP) is duidelijk en behoeft hier geen nadere toelichting. De tweede visie ${ }^{19}$ huldigt het uitgangspunt van de Embryowet dat menselijke embryo's enerzijds - vanwege hun vermogen uit te groeien tot een mens bescherming verdienen, maar dat die beschermwaardigheid anderzijds beperkt is, zeker gedurende de eerste dagen van hun bestaan. ${ }^{20} \mathrm{Op}$ basis van deze opvatting kan men verdedigen dat menselijke embryo's onder voorwaarden van onder meer proportionaliteit (belangrijk doel) en subsidiariteit (dat doel kan niet langs een minder problematische weg worden bereikt) gebruikt mogen worden voor wetenschappelijk onderzoek. Maar als deze redenering opgaat voor onderzoek met na IVF-behandeling overgebleven restembryo's, waarom geldt zij dan niet ook voor onderzoek waarvoor embryo's speciaal tot stand gebracht moeten worden? Het onderzoek waarvoor die embryo's zullen worden gebruikt is immers even instrumentaliserend, en voor de morele of juridische status van het embryo maakt de ontstaanswijze geen verschil. ${ }^{21}$ Dat restembryo's toch al gedoemd zijn verloren te gaan is een goede reden om geen nieuwe embryo's tot stand te brengen voor onderzoek dat ook met restembryo's kan worden uitgevoerd (subsidiariteit), maar er volgt niet uit dat restembryo's minder beschermwaardig zouden zijn. ${ }^{22}$ Degenen die desondanks een voor het normatieve debat relevant onderscheid zien, wijzen op een verschil in intentie waarmee de desbetreffende embryo's tot stand zijn gebracht. In de woorden van Van Beers: 'De aangekondigde wetswijziging maakt het mogelijk embryo's te creëren buiten de context van een beoogde zwangerschap. Daarmee wordt een principiële grens overschreden: het startschot is gegeven voor de productie van menselijk leven voor louter wetenschappelijke doeleinden (...). De komst van deze 'onderzoeksembryo's' introduceert een nieuwe categorie van menselijk leven: menselijk leven dat vanaf het eerste moment is voorbestemd om zuiver instrumentele in plaats van relationele waarden te dienen. ${ }^{23}$ Met andere woorden: anders dan onderzoeksembryo's zijn restembryo's tot stand gebracht op grond van een intentie die hen niet al vanaf het eerste moment tot middel voor een buiten henzelf gelegen doel reduceert. Dit zou juist zijn als ieder embryo dat in een IVF-behandeling ontstaat tot stand wordt gebracht met de expliciete bedoeling dit embryo in staat te stellen uit te groeien tot een kind. Maar de praktijk is anders: er worden in iedere hormoonstimulatiecyclus veel meer embryo's tot stand gebracht dan er verantwoord in één keer in de baarmoeder kunnen worden geplaatst. Doel van dat beleid is door selectie van het beste embryo de

19 Zie in dit verband ook het opiniestuk van B. van Beers: 'Debat over Embryowet hoort op hoogste politieke niveau', de Volkskrant 2 juni 2016.

20 Internationaal wordt voor onderzoek met menselijke embryo's een limiet van 14 dagen ontwikkelingsduur gehanteerd. Ook in de Embryowet is deze begrenzing opgenomen (art. 24e EW).

21 H.J.J. Leenen, J.C.J. Dute, J.K.M. Gevers, J. Legemaate, G.J.R. de Groot, M.E. Gelpke, E.J.C. de Jong, Handboek Gezondheidsrecht (zesde druk), Den Haag: Boom Juridische Uitgevers 2014, p. 354.

22 Vgl. (onderzoek bij) terminale patiënten: de omstandigheid dat ze toch wel dood zullen gaan, is geen rechtvaardiging voor minder rechtsbescherming.

23 Van Beers, 2016, a.w. 
kans op succes zo groot mogelijk te maken, maar de prijs is onvermijdelijk dat er embryo's ontstaan die niet de kans krijgen uit te groeien tot een kind: de zogenoemde restembryo's. Dat niet van te voren bekend is welk embryo voor plaatsing in de baarmoeder zal worden geselecteerd doet er niet aan af dat van tevoren wel duidelijk is dat de meeste embryo's daar niet voor in aanmerking zullen komen. Ze worden tot stand gebracht ter wille van het vergroten van de kans op een succesvolle zwangerschap. Men kan in dit licht moeilijk volhouden dat het creëren van embryo's met die intentie niet instrumentaliserend zou zijn. ${ }^{24} \mathrm{Als}$ het eerste te rechtvaardigen is in het licht van het belang van een zo effectief mogelijke IVFbehandeling enerzijds en de beperkte beschermwaardigheid van menselijke embryo's anderzijds, valt moeilijk in te zien waarom met het toestaan van het maken van embryo's voor (belangrijk en niet met andere middelen uit te voeren) wetenschappelijk onderzoek, 'een principiële grens wordt overschreden'. ${ }^{25}$ Het is van tweeën één: ofwel men vindt dat menselijke embryo's niet geïnstrumentaliseerd mogen worden, maar dan moet men iedere vorm van embryo-onderzoek én de huidige vormgeving van de IVF-behandeling afwijzen. Ofwel men vindt dat menselijke embryo's onder voorwaarden als middel mogen dienen voor belangrijke doelen zoals het vergroten van de succeskans van een behandeling of wetenschappelijk onderzoek, maar dan is er geen goede reden waarom ze wel voor het eerste doel en niet ook voor het tweede tot stand mogen worden gebracht.

Voor zover Van Beers in haar boven geciteerde opmerking suggereert dat het toestaan van het creëren van onderzoeksembryo's de deur openzet naar het instrumentaliseren van mensen, is dat een 'hellendvlakredenering' waarvoor geen grond bestaat. Niet alleen omdat, als gezegd, het instrumentaliseren van menselijke embryo's allang praktijk is, maar in de eerste plaats omdat embryo's geen mensen zijn. Wat met betrekking tot embryo's wel of niet wordt toegestaan, laat onverlet dat mensen nooit louter als middel behandeld mogen worden.

Er is nog een ander argument waarom sommigen die geen principiële bezwaren hebben tegen onderzoek met restembryo's vinden dat het tot stand brengen van embryo's voor onderzoek niet moet worden toegestaan. Daarvoor zijn immers gedoneerde eicellen nodig. De zorg is geuit dat dit kan leiden tot oneigenlijke druk op vrouwen om een belastende en riskante donorprocedure te ondergaan. ${ }^{26}$ Dit is geen onterechte zorg, waaraan in de brief van de regering ook ruim aandacht wordt geschonken. In de beide wetsevaluaties zijn voorstellen gedaan voor een nadere bepaling van de voorwaarden waaronder eiceldonatie voor wetenschappelijk onderzoek verantwoord kan zijn. ${ }^{27} \mathrm{Wij}$ zijn van mening dat de positie van de eiceldonor afdoende beschermd moet worden, maar zien daarin geen aanleiding voor handhaving van het verbod. ${ }^{28}$

Ten slotte de derde visie die in de reacties op het regeringsvoorstel valt te onderscheiden: als er geen steekhoudende argumenten zijn om uitsluitend wetenschappelijk onderzoek

24 Zie K. Devolder, 'Human embryonic stem cell research: why the discarded-created-distinction cannot be based on the potentiality argument', Bioethics 2005-2m, p. 167-186.

25 Van Beers, 2016, a.w.

26 Zie bijv. F. Baylis, 'Our cells/ourselves: creating human embryos for stem cell research', Women's Health Issues 2000-3, p. 140-145. Zie ook vragen PvdA en CDA, verslag van schriftelijk overleg over verruimingsvoorstel Embryowet.

27 Winter e.a. 2012, a.w.

28 Zie G.M. de Wert, W.J. Dondorp, 'Burgerperspectieven op embryo-onderzoek? Een gemiste kans'. TvGR 2008, p. 257-262; zie ook Winter e.a. 2012 a.w. 
met restembryo's toe te staan, en verruiming van de Embryowet op dit punt dus wenselijk is, rijst de vraag waarom die verruiming zo beperkt blijft als nu is voorzien. ${ }^{29}$ In de memorie van toelichting bij de Embryowet wordt het intentie-argument gebruikt om de nadere beperkingen te rechtvaardigen die de wet (in artikel 11) aan onderzoek met speciaal tot stand te brengen embryo's stelt. Die beperkingen zouden nodig zijn omdat 'het speciaal tot stand brengen van embryo's voor wetenschappelijk onderzoek een grotere inbreuk inhoudt op het respect voor menselijk leven dan wetenschappelijk onderzoek met embryo's die van een IVF-behandeling overblijven en die anders teloor zullen gaan.'30 Zoals wij hierboven hebben laten zien valt dat laatste niet vol te houden: van bedoelde 'grotere inbreuk' is geen sprake. En dus is de vraag waarom men aan wetenschappelijk onderzoek met speciaal tot stand gebrachte embryo's verdergaande beperkingen zou willen stellen dan de - in (artikel 10 van) de Embryowet voor wetenschappelijk onderzoek met restembryo's opgenomen - voorwaarde dat het 'redelijkerwijs aannemelijk is dat het onderzoek zal leiden tot nieuwe inzichten op het terrein van de medische wetenschap.' Die vraag rijst bij het limitatieve lijstje in artikel $11 \mathrm{EW}$, maar al helemaal bij de verdergaande beperkingen die in het voorstel van de regering in het vooruitzicht worden gesteld.

Ter afsluiting van deze paragraaf nog het volgende: Van Beers meent dat de verruiming van de Embryowet niet bij koninklijk besluit mag worden gerealiseerd. 'Een debat over de vraag hoe wij met beginnend leven omgaan, hoort op het hoogste politieke niveau plaats te vinden: niet bij koninklijk besluit, maar via het parlement', zo luidt haar stelling. ${ }^{31} \mathrm{De}$ vraag is waarom dat nodig zou zijn. Bij aanvaarding van de Embryowet is het parlement immers akkoord gegaan met delegatie aan de regering zoals in artikel 33 van de Embryowet omschreven (zie ook paragraaf 2). Aangezien destijds al was voorzien dat het verbod onder voorwaarden zou worden opgeheven, is er in ieder geval geen materiële reden om van dat delegatiebesluit terug te komen, althans wanneer de voorwaarden waaronder het verbod wordt opgeheven, gelijk blijven aan die welke reeds in de Embryowet zijn voorzien. Zoals wij hebben laten zien, wil de regering die voorwaarden kennelijk inperken en dat kan inderdaad niet zonder wijziging van de Embryowet. Overigens laat artikel 33 lid 2 EW ook zonder noodzaak van een wetswijziging enige ruimte voor nieuwe bemoeienis van het parlement. ${ }^{32}$

\section{Slot}

Het voornemen van de regering om meer ruimte te scheppen voor onderzoek met embryo's komt op de keper beschouwd neer op een nadere inperking van de mogelijkhe-

29 Zie vragen D66, verslag van schriftelijk overleg over verruimingsvoorstel Embryowet.

30 Kamerstukken II 2000/01, 27423, 3, p. 6. In de brief aangaande het verruimingsvoorstel wordt min of meer hetzelfde standpunt verkondigd, namelijk dat het belang van 'voldoende waarborgen voor zorgvuldigheid en respect voor de menselijke waardigheid' vraagt om de bedoelde beperkingen.

31 Van Beers, 2016, a.w.

32 Het bepaalt namelijk dat '[d]e voordracht voor dit besluit (...) niet eerder [wordt] gedaan dan vier weken nadat het ontwerp van het besluit is overlegd aan beide kamers der Staten-Generaal en evenmin indien binnen die termijn door of namens een der kamers of door tenminste een vijfde van het grondwettelijk aantal leden van een der kamers de wens te kennen is gegeven dat het tijdstip waarop onderdeel a van artikel 24 vervalt, bij wet wordt geregeld.' 
den die artikel $11 \mathrm{EW}$ biedt voor het speciaal creëren van embryo's voor wetenschappelijk onderzoek. In de situatie dat het verbod komt te vervallen, zal onderzoek met speciaal voor onderzoek gecreëerde embryo's slechts toegelaten zijn als het valt binnen een deel van de in artikel 11 aangegeven onderzoeksterreinen én indien het direct relevant is voor klinische toepassing. Fundamenteel onderzoek met speciaal tot stand gebrachte embryo's bliift voorlopig verboden. Afgezet tegen de huidige redactie en strekking van de bepalingen van de Embryowet betekent dit jammer genoeg een minder grote stap vooruit dan eerder door de wetgever voorzien. In haar beantwoording van de in het schriftelijk overleg gestelde vragen zegt de minister dat zij met dit verruimingsvoorstel 'een halve stap' zet en daarbij de mogelijkheid openhoudt 'om in de toekomst de volledige stap te zetten'. ${ }^{33}$ Waarom dat nu nog niet mogelijk was, blijft onduidelijk. In de brief wordt slechts gesteld dat met deze beperkte verruiming 'de menselijke waardigheid' wordt gerespecteerd. Maar uit de beantwoording van de gestelde vragen maken wij op dat die keuze in de eerste plaats berust op een beoordeling van het politieke en maatschappelijke draagvlak. ${ }^{34}$ Is het niet juist met het oog op de menselijke waardigheid van belang dat het niet bij deze 'halve stap' blijft? Voorkomen moet worden dat voor het welzijn en de gezondheid van mensen belangrijk wetenschappelijk onderzoek zonder goede redenen wordt belemmerd. 